\title{
Key questions on the outmoded Bernese policy on religion
}

\begin{tabular}{|c|c|}
\hline \multicolumn{2}{|c|}{$\begin{array}{l}\text { Authors: } \\
\text { Matthias G. Inniger }{ }^{1,2} \\
\text { Jacobus M. Vorster } \\
\text { Riaan Rheeder }\end{array}$} \\
\hline \multicolumn{2}{|c|}{$\begin{array}{l}\text { Affiliations: } \\
{ }^{1} \text { The Reformed Church Bern, } \\
\text { Bern, Switzerland }\end{array}$} \\
\hline \multicolumn{2}{|c|}{$\begin{array}{l}{ }^{2} \text { Unit of Reformed Theology } \\
\text { and the Development of the } \\
\text { SA Society, Faculty of } \\
\text { Theology, North-West } \\
\text { University, Potchefstroom, } \\
\text { South Africa }\end{array}$} \\
\hline \multicolumn{2}{|c|}{$\begin{array}{l}\text { Corresponding author: } \\
\text { Matthias Inniger, } \\
\text { matthias.inniger@bluemail.ch }\end{array}$} \\
\hline \multicolumn{2}{|c|}{$\begin{array}{l}\text { Received: } 23 \text { Apr. } 2021 \\
\text { Accepted: } 11 \text { Aug. } 2021 \\
\text { Published: } 29 \text { Nov. } 2021\end{array}$} \\
\hline \multicolumn{2}{|c|}{$\begin{array}{l}\text { How to cite this article: } \\
\text { Inniger, M.G., Vorster, J.M. \& } \\
\text { Rheeder, R., 2021, 'Key } \\
\text { questions on the outmoded } \\
\text { Bernese policy on religion', In } \\
\text { die Skriflig } 55(1) \text {, a2763. } \\
\text { https://doi.org/10.4102/ids. } \\
\text { v55i1.2763 }\end{array}$} \\
\hline \multicolumn{2}{|c|}{$\begin{array}{l}\text { Copyright: } \\
\text { (c) 2021. The Authors. } \\
\text { Licensee: AOSIS. This wo } \\
\text { is licensed under the } \\
\text { Creative Commons } \\
\text { Attribution License. }\end{array}$} \\
\hline \multicolumn{2}{|l|}{ Read online: } \\
\hline 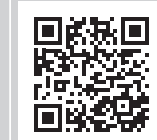 & $\begin{array}{l}\text { Scan this QR } \\
\text { code with your } \\
\text { smart phone or } \\
\text { mobile device } \\
\text { to read online. }\end{array}$ \\
\hline
\end{tabular}

This research highlighted the main purpose of a state policy on religion, which is to clarify the basic attitude of the state to religion, to grant individual and collective religious rights, to govern the relationship between state and religious communities, and to promote religious peace in a highly differentiated religious landscape. By presenting the Swiss Canton Bern as a case study, this research aimed to demonstrate that while the Bernese policy on religion for years did address the concerns of state, church and the religious needs of the majority of the population, it is today - as many other state policies on religion - outmoded, because it does not take into account the changing religious landscape. This policy includes and recognises only the declining traditional state churches, while it excludes and ignores growing churches and religious communities and the needs of their members. This research also intended to show that the Bernese policy does not pay enough attention to the positive and negative potential of religious communities. It furthers asymmetries between social groups and hinders the promotion of social cohesion. It also does not offer adequate answers to current concerns related to religion of the parliament, administration, public institutions and society. Considering the newest research and the insights from interviews with representatives of civil society, politics, government staff and academics, this research evinced clear responsibilities of a modern state in respect of religion, complex questions regarding state neutrality and equal treatment in terms of religion as well as current questions regarding the state's commitment to promoting social coherence and religious peace. This research argues that the Bernese policy on religion should be revised.

Contribution: This article contributes by presenting key questions on the outmoded Bernese policy on religion. These questions should not only guide the aims of politicians, researcher and the administration as they revise the policy, but also guide further research as part of my thesis. This article prepared the ground for further theological research, which will show that the adjustment of the Bernese policy on religion is also justified from Reformed perspective. Given the fact of the plural and secular religious landscape, theologically reconsidered principles regarding state policies on religion will pave the way to a creative and communitybuilding unfolding of religion in general, and specifically regarding the free development of the Bernese Reformed Church.

Keywords: changing religious landscape; confession-based policy on religion; history of the state-church relationship; inclusiveness of policies on religion; Reformed Church of Bern; religious peace; social asymmetries; social cohesion; social relevance of religious communities.

\section{Introduction}

The overall intention of the cumulative publication series is to academically accompany the revision processes of outmoded state policies on religion. While the first article ${ }^{1}$ of this research project outlined the general challenges posed by various confession-based ${ }^{2}$ state policies on religion due to changed religious landscapes in the Swiss ${ }^{3}$ and international context, this second article specifically considers the policy on religion of the Swiss Canton Bern. The Bernese state policy on religion serves as case study for this research project.

A brief overview of the history shows that the Bernese policy on religion - even if it was fairly inclusive for years - now has a problematic excluding and partially discriminating character. The policy has an either-or approach: either a religious community is included in the state policy, or it is excluded. This problem becomes increasingly obvious in the changing religious landscape.

\footnotetext{
1.The first article in this publication series is Changing religious landscapes challenge confession-based state policies on religion (Inniger Vorster \& Rheeder 2020).

2.Compare Portier (2017:212) who states that confession-based state policies on religion reflect the fact that a state has a relationship with one or more preferred confessional groups to which it grants privileges.
}

3.In Switzerland, matters related to the state-religion relationship are delegated to the 26 cantons. 
The Bernese policy on religion does not consider the current socio-religious reality. It does not include all churches and religious communities and the needs of their members, nor does it consider the increasing number of non-denominational citizens.

The ever-increasing numbers of non-denominational citizens also have needs regarding humanistic spiritual care in public institutions and some would like to be involved in statereligion issues, for example with respect to public funding of clergies' salaries and regarding religious-specific tax regulations. Moreover, the policy disregards the valuable contributions all churches and religious communities make to the common good and to social cohesion. It disregards the positive and the possibly negative social potential of all churches and religious communities and their contribution to religious peace. Furthermore, this policy does not fully meet the constitutional standards for state responsibility, neutrality, multipartiality and equal treatment. In the end, the policy is no longer able to give adequate answers to the current religious-specific concerns of the parliament, the administration and public institutions.

This research argues that amendments to the Bernese state policy on religion are required. It presents the current deficits and challenges as key questions. These key questions form the basis for the upcoming research, which offers considerations and perspectives on a policy revision to address these questions. Answers from a specific viewpoint of Reformed theology will be discussed after this second article. It is the intention of this research project to consider the revision processes on state policies on religion from a Christian-theological point of view.

\section{The inclusive and exclusive character of the Bernese policy on religion}

A brief conspectus - far from a detailed historical summary ${ }^{4}$ shows that the Bernese policy on religion either includes religious communities in an active state-religion relationship and in the state benefits, or it excludes and ignores groups and their members. The current design of this policy is an either-or approach.

The inclusive character of the policy is evident from a common bond between the State of Bern and the Bernese Reformed Church. This common bond is founded in the Reformation. Dellsperger (1991:118) states that the start of the Reformation in the State of Bern and the development of the modern Bernese state system cannot be viewed separately, as they are part of the same historical process. The development of the Bernese Reformed Church was not only a confessional, but also a highly political process, and the Reformation boosted the new State of Bern. According to Dellsperger (1991:124-130), the interlinkage between state and church 4.Detailed overviews on the history of state and church in the Canton Bern are given by Guggisberg (1958) and Dellsperger (1991). originates from the Bernese Reformation Disputation of 1528 and the Bernese Synodus of 1532 when the State of Bern embraced the Reformation and - at the same time - expanded its sovereignty over the church. The Reformed Church's pulpits became the place of government proclamations. The earthly authority of the State of Bern saw it as a part of its role to guide the people to righteous faith, to ensure true worship, the moral conduct of the population, the administration of the sacraments, and the institution of the clergy. The common bond between state and church prevails to this day. The State of Bern publicly and legally recognises the Reformed Church and pays the salaries of the clergy to the present day; the Synod of the Reformed Church still meets in the historic cantonal parliamentary building in Bern.

However, as time progressed, the Canton Bern did include other religious communities: In 1815 the Canton Bern entered into a union agreement that incorporated the area of Jura in its policy (Dellsperger 1991:151). The citizens from this area were predominantly Catholic. As a result, the State of Bern developed into a confessionally mixed canton. After giving Catholics permission to freely settle and to celebrate the Catholic Mass, the Canton Bern finally granted after a long process state recognition to the Roman Catholic Church and to the Old Catholic Church; the last-mentioned separated from the Roman Catholic Church as a result of the dogma of infallibility (Dellsperger 1991:167). In 1997, two Jewish communities (Canton Bern 2020a) were also included in the state policy on religion.

Despite the inclusions described above, the Bernese policy on religion also has an exclusive character. An example from recent history demonstrates this. In contrast to the inclusion of the Jewish communities in 1997, the request of the free churches for inclusion and state recognition was left unheard in 2007. These traditional Christian churches remained excluded from the policy by the argument of lacking legal foundations (Livenet.CH 2007). History shows that such exclusions have a long tradition in the Canton Bern. In earlier times, the state did not only exclude religious groups; it even prosecuted the Anabaptists. The Anabaptist communities developed during the early Reformation (Jecker 2012). These Christians stood up for more radical reforms. Aiming at restoring the original Christian faith, they distanced themselves from Luther and Zwingli. They refused to baptise their children and to accept the state's authority over religious communities. Further, they were against military service (Sarbach 2017). Dellsperger (1991:128) points out that the Bernese authorities aimed to 'eradicate[ing] this unchristian, evil-minded, irritating and rebellious weed' [author's own translation]. Penalties, imprisonment, deportations and death sentences were among the measures the Bernese state took against this Christian church. Only in the year 2017, the Canton Bern apologised to the Anabaptists for governmental persecution.

The tradition of excluding religious groups started during the Reformation, and for many centuries all free churches, 
which are playing an important role in the Bernese civil society, have never been included in the policy. Not only the free churches are excluded from the state policy and its blessings, ${ }^{5}$ but also the Orthodox, Anglican and Lutheran churches together with migratory Christian churches and all communities of Buddhist, Hindu, Muslim or other faiths.

During the political debates of 2015, the issue of whether the Bernese either-or policy is still appropriate, received as little attention as the issue of the general attitude the Canton Bern should adopt in respect of religion and its relationship to religious communities in the years to come. Discussions in the Bernese government and parliament merely involved a decision to adhere to the status quo of the outmoded religious political concept. First, the common bond with the religious communities that are included in the policy was confirmed by the means of a revised Church Law of the Canton Bern (Canton Bern 2020b:4). Secondly, the promised law of recognition, which would allow further communities to enter into a process of recognition (Canton Bern 2020c:5) as well as the announced and recommended (Inniger 2018:29-30) strategy of more inclusive governance of religious diversity (Canton Bern 2020d) was rejected. As the promised new orientation of this policy was not realised, the policy remains outmoded, especially with respect to its either-or approach of including or excluding groups, and the corresponding unequal treatment of groups and citizens. This policy creates problems that are increasing due to the changing religious landscape.

\section{The changing religious landscape increases current challenges}

Weller (2005:71) describes today's religious landscape in the United Kingdom as Christian, secular and plural. This description is also true for Switzerland (Inniger, Vorster \& Rheeder 2020:3-4). Figure 1 (cf. Swiss Federal Statistical Office 2020a) shows that, even though the alienation from traditional state-recognised churches is obvious, Christianity still characterises today's Swiss religious landscape. In the Swiss context, Christianity, however, is no longer the monopolised state-church Christianity, but a diverse Christianity, which includes a considerable number of churches that are not by law established. Moreover, there is a new socio-religious reality where the Christian monopoly no longer exists: The religious landscape is plural with Jewish, Muslim, Alevi, Hindu, Buddhist and other religious affiliations. It is also more secular with an increasing number of citizens who do not adhere to any religious affiliation.

Figure 2 below makes obvious the decrease in numbers of the Catholic and the Reformed state churches throughout Switzerland. It also shows the growth of the non-staterecognised Christian churches and the religious communities of different religions in Switzerland, and the growing section

5.The expression of blessings was intentionally used, as state-recognised religious communities benefit from many advantages such as paid salaries for the clergy, access to university training for clergy and chaplains in public institutions, access to the state tax system for collecting church taxes, and social recognition.

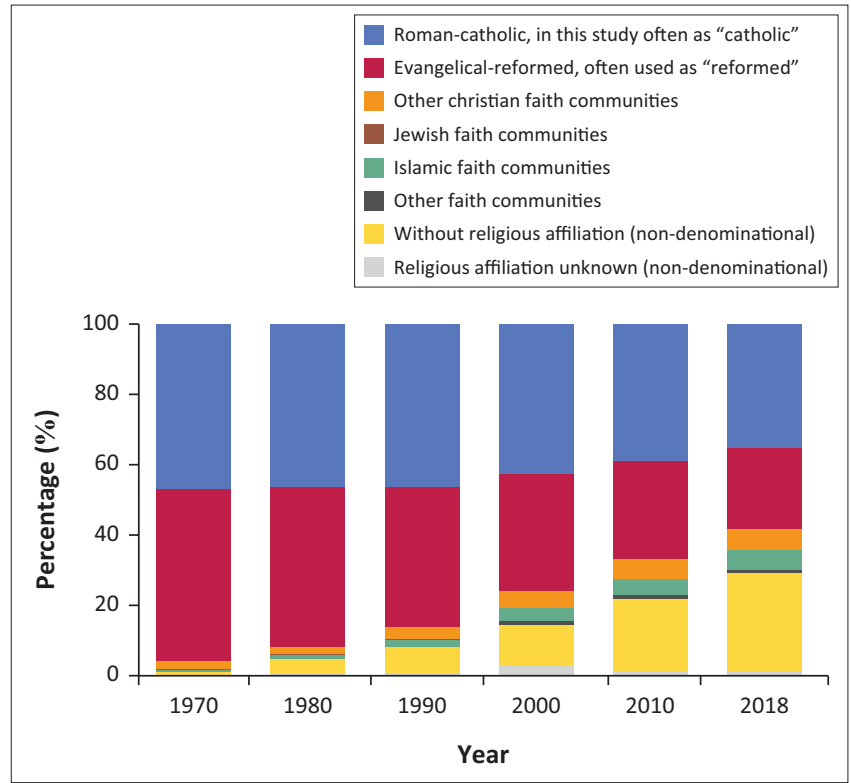

Source: Swiss Confederation, 2020a, Federal Constitution of 18 April 1999 (Status as of 1 January 2020), viewed 04 October 2020, from https://www.admin.ch/opc/en/classifiedcompilation/19995395/index.html.

FIGURE 1: Development of the religious landscape. Chart of the Swiss Federal Statistical Office 2020a.

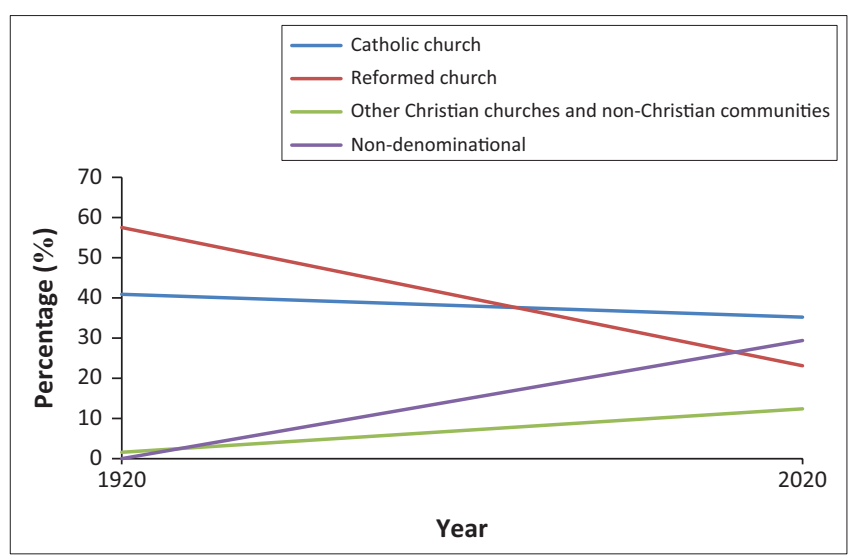

Source: Adapted from Swiss Federal Statistic Office, 2020b, Religious affiliation since 2015 viewed 11 April 2020, from https://www.bfs.admin.ch/bfs/de/home/statistiken/ bevoelkerung/sprachen-religionen/religionen.assetdetail.11607242.html.

FIGURE 2: Development of the religious landscape throughout Switzerland from 1910-2018.

of the population without any specific religious affiliation (Swiss Federal Statistical Office 2020b).

Figure 3 shows that the development in Figure 2 is highly relevant with respect to the state-religion relationship expressed in many Swiss cantonal policies on religion. Figure 3 presents the Catholic and Reformed churches, the two largest state-recognised bodies in the Swiss cantons, delineated together as the group 'included in state policies on religion'. In 1920, this group included the majority of the population; so state policies on religion were fairly inclusive. The decrease in the numbers of this group and the growth of the group 'excluded from state policies on religion' - the churches and religious communities not by law established and the non-denominational population - is remarkable. Today's Swiss policies on religion are generally lacking the necessary inclusiveness of a state policy on religion. Figure 3 


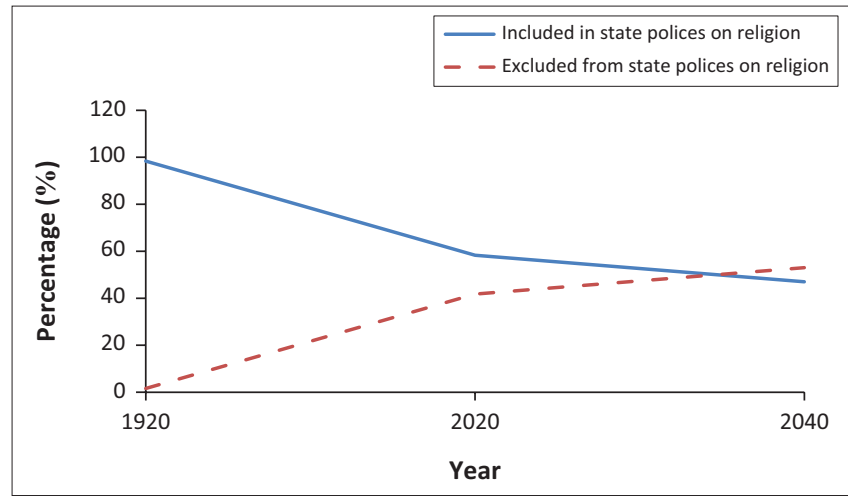

Source: Adapted from Swiss Federal Statistic Office, 2020b, Religious affiliation since 2015 viewed 11 April 2020, from https://www.bfs.admin.ch/bfs/de/home/statistiken/ bevoelkerung/sprachen-religionen/religionen.assetdetail.11607242.html.

FIGURE 3: The decline in numbers of the groups included in state policies on religion, and the growth of the groups excluded from policies throughout Switzerland, from 1910-2018, with a trend option.

predicts - in accordance with my recent study (Inniger 2018:10) - the trend ${ }^{6}$ of the continuous decline in numbers of the groups included in policies and the continuous growth of the groups excluded from the policy. Consequently, Swiss cantonal governments and parliaments should become aware of the fact that outmoded and unadjusted state policies on religion will sooner or later benefit a social minority while excluding the majority of the population and their religious or spiritual needs. This insight challenges the confessionbased policies on religion that were established in and for another socio-religious context.

Table 1 shows that the religious landscape of the Canton Bern aligns with the general Swiss context. The specific religious landscape of the Canton Bern aligns with the general Swiss context. Even if the dominant Bernese Reformed Church has been notable in this canton for centuries, the Canton Bern is also diversly Christian, plural and secular. It was showed in the report on behalf of the Bernese government that the Bernese state policy on religion only includes the Reformed, the Catholic and the Old Catholic churches together with two Jewish communities. All other churches and religious communities are excluded from the policy (Inniger 2018:9).

It was mentioned in the report on behalf of the Bernese government that, in the year 2018, 68\% of the Bernese population still belonged to religious communities included in the state policy on religion, $12 \%$ belonged to religious groups excluded from the policy, and $20 \%$ to the nondenominational population (Inniger 2018:9).

The decline of the Bernese Reformed Church, however, is developing in quick steps. While 100 years ago, almost all citizens belonged to this church, it lost 210175 members from 1990 to 2018 (Inniger 2018:10). Since the publication of the report in 2018, the members of the Reformed Church fell below 50\% of the population (Canton Bern 2020e). This church is suffering an average yearly loss of 7506 members (Inniger 2018:10; Reformed Churches Bern-Jura-Solothurn
TABLE 1: Religious landscape in the Canton Bern.

\begin{tabular}{|c|c|c|c|}
\hline $\begin{array}{l}\text { Status of the } \\
\text { religious community }\end{array}$ & Variable & $\begin{array}{l}\text { Resident population } \\
\text { older than the age } \\
\text { of } 15\end{array}$ & $\%$ \\
\hline \multirow{4}{*}{$\begin{array}{l}\text { Recognised by the } \\
\text { state (ca. } 68 \% \text { ) }\end{array}$} & Reformed & 442500 & 52.1 \\
\hline & Catholic & 133000 & 15.8 \\
\hline & Old Catholic & 2000 & 0.2 \\
\hline & Jewish communities & 900 & 0.1 \\
\hline \multirow[t]{3}{*}{$\begin{array}{l}\text { Not recognised by } \\
\text { the state (ca. } 12 \% \text { ) }\end{array}$} & $\begin{array}{l}\text { Christian churches not } \\
\text { recognised by the } \\
\text { Canton Bern }\end{array}$ & 55500 & 6.6 \\
\hline & $\begin{array}{l}\text { Islamic religious } \\
\text { communities }\end{array}$ & 33700 & 3.9 \\
\hline & $\begin{array}{l}\text { Hindu, Buddhist, Sikh } \\
\text { and further religious } \\
\text { communities }\end{array}$ & 13600 & 1.7 \\
\hline \multirow{2}{*}{$\begin{array}{l}\text { Non-denominational } \\
\text { (ca. } 20 \% \text { ) }\end{array}$} & Non-denominational & 168900 & 18.5 \\
\hline & Unknown & 9400 & 1.1 \\
\hline $100 \%$ & Total & 859500 & 100.0 \\
\hline
\end{tabular}

Source: Adapted from Canton Bern, 2020e, Finance Department, Permanent resident population ( 15 years and older) by religion and denomination, in 2018, viewed 02 September 2020, from https://www.fin.be.ch/fin/de/index/finanzen/finanzen/statistik/bevoelk/religionen.html; Inniger, M., 2018, Religionspolitische Auslegeordnung für den Kanton Bern: Kurzbericht im Auftrag der Justiz-, Gemeinde- und Kirchendirektion des Kantons Bern (3 April 2018), viewed 02 September 2020, from https://www.jgk.be.ch/jgk/de/index/direktion/ueber-die-direktion/ dossiers.assetref/dam/documents/.

1990). The trend does not stop here. Based on the trend calculation (cf. Figure 3), all state-recognised churches, added together, will likely fall below the $50 \%$ mark in the Canton Bern within the next few years (Inniger 2018:10).

To conclude, the either-or approach of the Bernese state policy on religion is a growing problem due to the development of the religious landscape of the Canton Bern. The Bernese policy on religion is one for a part of the population and not for the whole population. A wide array of challenges and question therefore confronts this policy. The key questions with respect to the Bernese policy on religion are identified in the section below.

\section{Key questions with respect to the outmoded Bernese policy on religion}

Although the Bernese policy always had a tendency to exclude and ignore certain religious groups and their members, for decades it generally fulfilled its purpose, because it included the vast majority of the population. However, the changing religious landscape of the Swiss Canton Bern is challenging the appropriateness of its policy on religion. Due to demographic and societal changes, this policy is increasingly running into problems. More and more churches, communities, citizens and needs surrounding religious matters are not considered by this policy, which grew from a different socio-religious context. In what follows, the key questions ${ }^{7}$ that currently

7.These key questions, based on a study of documents and conducting one-on-one interview using the technique of Bortz and Döring (2006:95-136, 295-350; cf. Inniger 2016), were identified. According to Bortz and Döring (2006:299), a reality can best be evaluated by a qualitatively oriented interpretative method such as personal interviews with open questions. This approach permits a researcher to ask the interviewees to mention meaningful experiences and insights or to express thei opinions (Bortz \& Döring 2006.296). The research conversations and informa opinions (Bortz \& Dönn 2006.296). The research conversations and informal interview, following a schedule of open questions corresponding to the subject of this research (Bortz \& Döring 2006:308-309), contributed substantially to the gathering of sufficient valid information. The participants validated the information by revising the written version of the interview (Bortz \& Doring 2006:296) target group for the interviews were representatives of civil society, politics, government staff and academics. The inclusion criteria for participants were that conversation partners either had to have academic expertise and/or practical 
challenge this policy and that should be answered during a revision process have been identified.

\section{Questions on the state's attitude towards religion}

The Bernese policy on religion gives rise to general questions regarding the basic attitude of the state to religion, to spirituality and to the sacred. A state that respects the fundamental qualities and values of life that go beyond the material and mundane, and by which people orientate and make sense of their lives, respects, together with its institutions, the dimensions of religion, spirituality and the sacred (Cobb 2015:3; Inniger 2016:208). The Canton Bern expresses its respect for these dimensions, for example, in the preamble of its Constitution (Canton Bern 2020f.), which states that Bernese people live together under the responsibility to the creation. Moreover, it expresses this respect by institutionalising chaplaincy in public institutions (Canton Bern 2020g: Art. 53). This respect is also evident from the fact that the Canton Bern has a relationship with chosen religious communities.

The Canton Bern has not yet defined its basic attitude to religion, spirituality and to the sacred. It is also far from redefining the criteria based on which the state maintains a relationship with a given religious community. The Canton Bern owes it to its citizens to clarify these unanswered questions. A basic statement on these fundamental questions would make future debates on state-religion issues more objective. Such a basic commitment is currently utterly absent.

\section{Questions on the social relevance of religious communities}

According to the revised cantonal Church Law, the Canton Bern sees the value and positive potential of the former state churches, as they relevantly contribute to social life (Canton Bern 2020h: Art. 29-31). Following the current state of research, religious communities generally support the interweaving of society and social life: They positively contribute with welfare benefits for the whole of society, to norm-setting and to building values in the civil society (Göransson 2014). By doing this, they support important goals of the state itself and help to build a robust civil society (Van Bijsterveld 2018:21). Consequently, it is an advantage for a state if it considers and promotes the positive social and value-building potential of religious communities.

It has been shown that the churches and religious communities, which are not state-recognised, also have positive potential, and that these social groups can relevantly

experience regarding religious policy, and that they had to have a multipartial attitude regarding the diverse religious groups. The view of the participants from religious communities will be included in the follow-up article that concerns the development of churches and religious communities. The interviews have been audio-recorded and documented by means of a written summary that was validated audio-recorded and documented by means of a written summary that was validated by the interviewees. The data are managed by the researcher under the supervision of the North-West University, South Africa. The ethics code of the TRREE (Training and Resources in Research Ethics Evaluation) programme on the ethics and the regulation of health research involving human participants were taken into consideration (Bortz \& Doring 2006:41-45, 106-109; TRREE 2017). The Canton Bern gave its approval for this study. The interviews took place from 28 June 2019 to 09 January 2020. contribute to the common good of society too (Inniger 2018:16-18). The churches and religious communities that are currently being ignored by the Canton Bern also give a home, support and security for their members and beyond. They support the integration efforts of the state and its institutions, and they contribute to education. They support the children of their communities in navigating a plural society. They help their members with solving conflicts and with welfare activities, give financial support to pauperising people, and give spiritual care and support in crisis. They furthermore contribute to interreligious dialogue and to the promotion of social peace among religious communities. Lastly, the non-state-recognised churches and religious communities contribute also to cultural and economic activities and achievements (Inniger 2018:16-18).

Schuppert (2017:127-136, 171-172, 185) confirms this by stating that religious communities in general are relevant as identifiable communities and as governance collectives which are, in respect of the state, power factors. According to Schuppert (2017:183-188), religious communities in principle have a large capacity for collective action; they possess transnational power to build institutions, to set rules and to make laws. As such they are stakeholders in respect of the state. In view of the manifold effects that churches and religious communities can have on the state and civil society, it is in the best interest of a state to interact with all social groups that form part of the current religious landscape (Inniger 2018:6).

A policy on religion should also consider the possible negative influence that churches and religious communities can have (Inniger et al. 2020:5). If churches and religious communities are not considered by the state and not included in the corresponding benefits, they cannot participate in social life in the same way as traditional state churches do. If they have no resources, no well-trained personnel, no accesses and no social recognition, because the state does not recognise and support them, they cannot develop their full positive potential for state and society. Furthermore, if the state ignores religious communities and their social relevance, it jeopardises their potential to identify with the aims of state and society. In the worst case, they are developing as parallel societies.

While the Canton Bern considers the social relevance of the former state churches, it does not consider the social relevance and the potential of those churches and religious communities that are still excluded from the state policy. Leutwyler (pers. comm., 29 October 2019) stresses that the state should consider, appreciate and reimburse the relevant social contributions of these churches and religious communities that are as yet unrecognised by the state. Engi (pers. comm., 30 October 2019) confirms that governments should explain the importance of all religious communities, specifically with respect to their social contributions. H. Schmid (pers. comm., 09 January 2020) also agrees that the state should support the social projects of non-state-recognised religious communities. 


\section{Questions on the social cohesion and religious peace}

As mentioned above, churches and religious communities are, as a part of the civil society, socially relevant. When it comes to the state commitment to promoting social cohesion and ensuring social peace among religious communities, the inclusion of all communities in this process is important. In view of tensions between different religious communities during the 19th century (Inniger 2019:83-85), the Swiss Confederation considers measures to preserve social cohesion and religious peace as relevant. This commitment has a prominent position in the Swiss Federal Constitution (2020a: Art. $72^{2}$ ). Based on this, the Canton Bern has an explicit responsibility to promote peaceful interaction between religious groups (Inniger 2018:26).

If, however, the Bernese policy considers and advantages chosen groups and ignores others, the state itself is furthering social asymmetries. These asymmetries can imply discriminatory aspects (Inniger 2018:25). The churches and religious communities that are being ignored by the state are sometimes relegated to an existence under the carpet of society, especially with respect to the social recognition. Politicians in the Bernese parliament have noted this fact and have tried to further the public and social recognition of ignored churches and religious communities with the main intention to convey them the same 'clearance certificate' (Schmid 2017) that state-recognised communities enjoy, and to increase their involvement in the process of promoting social cohesion and religious peace. The current policy, however, furthers unequal treatment, injustices and asymmetries and, above all, it irritates the social cohesion and the long-term safeguarding of religious peace.

These open questions should be answered optimally with a sustainable religious-political overall arrangement (Schuppert 2017:225ff.; A. Tunger-Zanetti, pers. comm., 30 July 2019).

\section{Questions on state responsibility}

In view of the new socio-religious realities and the corresponding effects of state policies on religion, the Canton Bern is also lagging behind with regard to the direct state responsibility on religious issues. The Canton Bern has the responsibility to make transparent its attitude towards the phenomenon of religion, the sacred of state and citizens, issues of religion in public places, and towards the implementation of religious rights. This would include spiritual care in public institutions, burial grounds for all citizens, or a tax system which treats all religious communities and citizens equally. Furthermore, the Canton Bern is, based on its Constitution, responsible for equal and non-discriminating treatment of religious communities and individual citizens as well as for ruling state-religion issues in a way that promotes social cohesion and public peace (Inniger 2018:11).

The Canton Bern also has specific responsibilities regarding religious issues because of its exclusive relationship with chosen religious groups and its denial of other religious groups. Due to this fact, the state itself is co-responsible for possible asymmetries between religious groups (Inniger 2018:20). It is promoting two classes of communities based on its policy, which is not ideal. The policy on religion of the Canton Bern is co-responsible for some groups receiving no public support. As a result, these groups have less opportunity to participate in the civil society, which can lead to problematic developments in religious communities (Inniger 2018:25-26). In this respect, Dehbi (2020) has shown that systematic exclusion can, under circumstances, further tendencies of radicalisation. If, however, state measures regarding religiously caused radicalisation only involves regular controls in places of worship of not-state-recognised churches and religious communities, these measures are obviously falling short. If the state wants to address the problem of radicalisation at its roots, it should promote access to institutions, participation and social recognition of churches and religious communities that have thus far been neglected by the state.

Recent postulates and motions of the Bernese parliament also confirm the direct responsibilities of the state regarding religious issues. Bernese members of parliament (M. Koelbing [Political motions regarding religious issues] pers. comm., 12 July 2018) have reminded the state, government and parliament of their responsibility regarding religious issues. The state of Bern has, for example, accepted the following postulates and motions, namely for the establishment of a 'Bernese Charta of Religions' (Postulat Hamdaoui, 2017. RRGR.535, cf. Inniger 2018:33-34), for a 'European Islam' (Motion Evangelical Popular Party, 2015.RRGR.283), and for a more diverse chaplaincy in public institutions (Motion Stähli, 2017.RRGR.702).

Furthermore, extended evaluations (Inniger 2017; 2018) have shown that the state bears a direct responsibility regarding concerns on the cantonal, regional and communal authorities and administration. Many of these authorities request religious-political support from the state in the fields of integration, care for elderly and disabled citizens, schools, penal institutions, asylums, policy and civil protection. The evaluation (Inniger 2017:84-94) on behalf of the Canton Bern shows how cantonal authorities have reminded the Bernese government of its direct responsibilities with respect to religious issues.

Interviewees confirm that the Canton Bern should assume its wide-ranging responsibility regarding religion and religious communities. Tunger-Zanetti (pers. comm., 30 July 2019) mentions the responsibility of the state to manage religious diversity justly, which involves equal treatment of all groups and citizens. Koelbing (pers. comm., 28 June 2019) mentions that it is one of the most urgent responsibilities of the Canton Bern to send to all churches and religious communities a clear signal that the state is aware of all relevant groups; moreover, that the state will enter a dialogue with all of them. Either way, the state's responsibility with respect to religious issues and its relationships with religious groups is not being met in the Canton Bern. 


\section{Questions on state recognition}

The Bernese policy on religion recognises traditional Christian state churches. The origin of state recognition lies in the 19th century when almost $100 \%$ of the population belonged to the state churches. By offering this legal status, the state took a first step in the separation of state and church, and state and religion (Inniger 2018:25). In contradiction with this act of separation, state recognition today has turned into a privilege that involves preferential treatment and social recognition for state churches. The Bernese policy is currently weighed down by its tradition of recognising religious groups that have been losing members and social relevance, while growing groups are completely ignored and go from the state empty-handed.

The state refused public and legal recognition of these growing groups. This refusal is clear from the fact that the constitutionally promised cantonal law of recognition, which is meant to open doors to timely and inclusive governance of religious diversity, has in recent years been disregarded. Lack of state recognition results in a lack of social recognition (Inniger 2018:21). Religious communities that lack state recognition, stand in the corner of the society as marginalised or even suspect religion. The Hindu patient in a hospital is a 'special case' when it comes to the chaplain's service. Families with Muslim backgrounds must, in many Bernese municipalities, bring a grandfather who had lived and paid taxes for years in the Canton Bern in the country of his origin for the burial, because there are no Muslim burial grounds. The Orthodox, Anglican, Lutheran or free church pastor who celebrates Easter with the prisoners of his or her Christian faith may in some cases not even celebrate the ceremony in the chapel, because he or she is not part of a state-recognised church. By the policy of recognition and the refusal of recognition, the state divides churches and religious groups and their members in two classes; by doing so, it creates asymmetries (Inniger 2018:21). In view of the demographic development, the Bernese policy of recognising and of refusing recognition is under pressure when it comes to justifying such a strategy (A. Tunger-Zanetti, pers. comm., 30 July 2019). The system of recognising and not recognising is being pushed to its limits in view of today's religious landscape and the resulting challenges (L. Engi, pers. comm., 30 October 2019).

\section{Questions on the lack of inclusiveness of the policy}

The purpose of a state policy on religion is to rule religious issues for the whole population of the state. The Bernese policy is, due to the changing socio-religious realities, becoming increasingly dated given its exclusive character. The Canton Bern and its institutions are frequently confronted by various situations neither included in the policy nor considered by it, for example regarding chaplaincy, taxes or registration systems, or burial fields.

Experts commissioned by the Bernese government mentioned in 2014 already that when the state-recognised groups become a minority (Ecoplan, Ad!vocate 2014:121-122), the policy would be threatened by a legitimacy deficit. Other interviewees confirm open questions on the lacking inclusiveness of the Swiss cantonal policies on religion. In view of a pluralistic society, a state should, according to $\mathrm{H}$. Schmid (pers. comm., 09 January 2020), include a wide range of different religious affiliations in the public sphere by means of its policy: education, social work and chaplaincy are no longer monopolies held by the former dominant state churches. Groups that are not recognised by the state have developed into relevant entities that should be included in policies on religion. Engi (pers. comm., 30 October 2019) mentions that the current state-church system is too inflexible; it is no longer appropriate for dealing with the dynamic religious landscape. The state should develop a more inclusive system that treats religious communities equally. Stähli (pers. comm., 24 September 2019), responding to the question of the lacking inclusiveness of the policy, sees no reason why chaplains of non-state-recognised churches and communities should not be included in the chaplains' service in public institutions.

According to Heckel (2009:380-381), the concept of a statereligion agreement should be interpreted in an inclusive, pluralist and universalistic way.

\section{Questions on state neutrality}

The Bernese policy on religion can also be questioned on state neutrality and - corresponding to neutrality - regarding the state's multipartial attitude. The possible discriminating aspects of a policy that is not consistently neutral have been pointed out, for example, if religious communities enjoy social recognition, because the state recognises them while other religious communities do not benefit from this advantage (Inniger 2018:25-26).

Pfaff-Czarnecka (2009:225-257) confirms that Swiss cantonal policies are not neutral, because they are driving a wedge between the two classes: the groups included by the policy and the groups excluded from the policy. Pfaff-Czarnecka (2009:252) states that Christianity clearly is the only staterecognised religion, while non-Christian communities are 'explicitly and legally ... denied public standing as well as support ...'. She (Pfaff-Czarnecka 2009:233) mentions that neutrality of the state implies impartiality, 'but obviously the elevated position of the Christian churches in comparison with other religious communities indicates asymmetries ...' ${ }^{8}$

Engi (2017:16) mentions that a religiously neutral state should have 'sufficient distance' from all churches and religious groups. He (L. Engi, pers. comm., 30 October 2019) brings up state neutrality when he duns the state for fair treatment of all religious groups and all citizens. In this context, Neuhaus,

8.I agree with Pfaff-Czarnecka on the view that the state is driving a wedge betwe.... religious groups, and that Swiss cantons systematically and enerlly ignore nonreligious groups, and that Swiss cantons systematically and generally ignore nonChristian groups. In this context it is, however, important to mention that many Christian churches and communities are also explicitly and legally denied public standing and support. Pfaff-Czarnecka mentions the privileged treatment of the former Christian state churches by the government without mentioning the numerous state-ignored Christian denominations. 
State Council of the Canton Bern, mentions that the secular state should not identify with one specific religious group; rather it should grant parity by taking the necessary distance from religious institutions (Canton Bern 2015). In view of these statements and because the Swiss Federal Supreme Court (1992: BGE 118 Ia 58) also proclaimed that a modern constitutional state must be neutral regarding religion and religious communities, unanswered questions regarding state neutrality and multipartiality are obvious in the Canton Bern.

\section{Questions on the legal framework}

Many unanswered questions are obvious when it comes to the legal framework within which the Bernese policy on religion is embedded. This legal framework does not seem flexible enough to accommodate the recent challenges. For example, the Canton Bern rejected the wish of the free churches for inclusion in the policy with the argument that the legal foundations are lacking (Livenet.CH 2007). Given this legal framework, the Canton Bern cannot respond adequately to current challenges posed by its policy on religion, which was in fact drawn up in and for another socio-religious reality.

The legal framework in the Canton Bern looks as follows: According to the Swiss Federal Constitution (2020a), the Swiss Confederation is co-responsible with the 26 cantons to protect public peace among religious communities (Art. $72^{2}$ ). Furthermore, it guarantees the right of all citizens to equal treatment. No citizen may be discriminated against, specifically not based on his or her religious views (Art. $8^{1-2}$ ). These fundamental rights include, besides freedom of religion and conscience, the dictate of tolerance towards minority groups (Art. 15), also towards religious minorities. Apart from that, the Swiss Confederation (Art. $72^{1}$ ) delegates the responsibility for state-religion issues in principle to the level of the 26 cantons. In the Canton Bern, the government is responsible for ruling on religious issues for the whole population. As a part of this responsibility, the Bernese Cantonal Constitution (Canton Bern 2020f.) guarantees, besides freedom of religion and conscience (Art. 14), legal equality and protection against discrimination (Art. 10). The Constitution obliges the Canton Bern to meet the needs of minorities and to consider the right of human dignity (Art. 4). The Bernese Constitution provides the legal framework for chaplaincy in cantonal public institutions such as homes, prisons and hospitals. The Canton Bern regulates the chaplaincy, for example in public hospitals, by a decree that mentions that hospitals have to guarantee chaplaincy for patients of all religions (Canton Bern 2020g: Art. 53). The most far-reaching precedent of the Bernese legal framework, however, is the fact that the state has a relationship to certain, but not to all religious communities (Canton Bern 2020f. Art. 121-126).

This legal framework can be explained by looking at its historical origin. In view of socio-religious realities, today it provokes asymmetries between religious communities and their members that are differently treated by the state. The state itself creates two classes of religious communities with its unadjusted legal framework (Inniger 2018:25).

As mentioned above, the Canton Bern decided in 2015 to abide by this legal framework. It even fortified the relationship with traditional churches by renewing the established Church Law. Moreover, it intentionally decreased the chance of state recognition and privileges for further religious communities (Canton Bern 2020d), even though the Bernese Cantonal Constitution (Art. 126 ${ }^{2}$ ) states that further communities could be recognised by public law, and that a law of recognition should rule the requirements. The result of the debate was not to keep the promise as referred above of establishing this law.

By accepting and even solidifying this inadequate legal framework, unrecognised churches and religious communities remain 'second class religions' (Inniger 2018:25). Free churches, Orthodox, Lutheran, Anglican, Methodist and Baptist churches as well as Hindu, Buddhist and Muslim communities at best can be, in the words of the Swiss Federal Civil Code (Swiss Confederation 2020b: Art. 60), communities 'under private law'. They, however, remain excluded from the Bernese Church Law that explicitly rules issues of state and religion. As a result, ignored groups and their members are disadvantaged with respect to state founding, tax exemptions, public access and social recognition. Their members suffer under unequal treatment, for example regarding chaplaincy, burial grounds and the registration and taxation system.

Among the interviewees, Reber (pers. comm., 01 October 2019) questions the basis for the legitimacy of such an imbalance. He asks how the Canton Bern can justify a legal framework that includes certain religious communities while it ignores others. While Tunger-Zanetti (pers. comm., 30 July 2019) mentions that the Canton Bern is under pressure regarding the justification of the current legal framework, Engi (pers. comm., 30 October 2019) confirms that Swiss cantons are in fact being challenged on establishing a legal framework on which basis the relationship between state and all religious communities can evolve, and he wonders whether political majorities can be found to create a reconsidered legal basis. Köpfli (pers. comm., 27 November 2019) refers to the historical legal titles the Reformed Church claimed: On 07 May 1804 the State of Bern appropriated church property by committing to pay the salaries of the Reformed clergy (Canton Bern 2020i:11-12). Köpfli, when asked about the legal framework, sees the replacement of these legal titles as urgent.

According to Schuppert (2017:197), modern liberal states have the possibility of developing their relationship to all religious communities as governance actors (pp. 168-188). A state can respond to the current requirements of a changing religious landscape by adapting and widening the legal framework (Schuppert 2017:225ff.). A reconsidered legal framework could define the basic understanding of the statereligion relationship and public funding of religious 
communities. It could deal with issues of the interaction between the religious communities, and rule on open questions in respect of the religious rights of individuals, for example regarding taxation, chaplaincy in public institutions, and burial grounds. Such an order could be an appropriate modus vivendi for peaceful coexistence. In this respect, Heckel (2009) states:

The Constitution requires the fundamental equal treatment of the 'old' and the 'new', and of the big and the small religious communities, in order to rule the pluralistic present days in a liberal and forward-looking way that orients itself at the value of equal opportunities. Especially this new way to rule should not reinforce outdated arrangements. The constitution guarantees to the individuum to dissolve from old bonds, and to the religious communities to form groups, to interact and to fulfil religious obligations. [...] The concept of religion has to be interpreted in a pluralistic and universalistic way in the constitution. (pp. 380381, [author's own translation])

Being founded during a period when the majority of the population belonged to the Reformed Church, the legal framework of the Canton Bern is not prepared to respond to current challenges by means of an inclusion-oriented approach or to support the development of a fair, progressive, peacebuilding and inclusive state-religion policy.

\section{Questions on the lack of state resources}

The Canton Bern also suffers from an obvious lack of resources. Timely governance of religious diversity requires resources such as enough staff, ideally well-positioned teams of social and legal practitioners, together with experts of socio-religious issues. In view of the huge responsibility, challenges and political motions regarding state-religion issues, the Canton Bern does not have enough personnel, especially for the creation of an ongoing dialogue with churches and religious groups and with the staff of state, regional and communal administration, police, school and institutions who need support regarding religious issues. The Canton Bern also lacks resources with respect to a strategy to develop a more inclusive governance of religious diversity. A new, timely institutional arrangement of statereligion issues needs besides staff and knowhow a clear strategy.

\section{The complexity of the emerging questions}

Considering the complexity of the current state-religion challenges, key questions on the Bernese policy on religion were identified. Interviewees confirm the complexity of these questions and challenges. According to Jost (pers. comm., 29 July 2019), there are too many unanswered questions to dismiss the drafting of a revised fair and inclusive policy on religion. Reber (pers. comm., 01 October 2019) emphasises the importance of an inclusive policy that responds to the complexity of the key questions and challenges. Engi (pers. comm., 30 October 2019) emphasises that the Swiss cantons are specifically challenged by the lack of an appropriate legal framework. The Bernese state policy on religion should be revised. This revision should respond to the unanswered key questions presented in this article.

\section{Conclusion and outlook}

While the previous article (Inniger et al. 2020) highlighted general aspects related to the fact that changing religious landscapes have a significant impact on confession-based state policies on religion in many contexts, in this article, the focus was on the specific situation in the Swiss Canton Bern. It is evident that the Bernese policy on religion includes and advantages traditional state churches, while it excludes and ignores other churches and religious communities as well as the needs and concerns of their members, and partially also of the non-denominational population. This unequal treatment was less problematic during the time when the state churches included the vast majority of the population. Today's religious landscape, however, has resulted in a situation where the policy would sooner or later only include a social minority, while many groups will remain unconsidered and excluded, and the needs of their members would remain unaddressed. The pressure to justify a policy that now already treats groups and citizens unequally and which hinders the promotion of social cohesion and religious peace, will increase in the nearer future. This article shows the new socio-religious realities in the Canton Bern and the resulting challenges posed by the Bernese policy on religion. It presents the complex key questions confronting the Canton Bern. Obviously, the current policy is outmoded. There is a need for reconsideration and revision. It is in the state's interest to clarify its basic attitude towards religion and to include all socio-religious stakeholders in its consideration.

The next (third) article in the thesis on state-religion issues in the Swiss Canton Bern will ask which principles the Canton Bern should consider and eventually define when revising the outmoded policy. This consideration will include theological arguments as this study takes a Reformed theological perspective. During the recommended revision, the key questions presented in this article should be taken into consideration. The establishment of a fair, progressive and peacebuilding policy on religion is the aim of the processes considered in this research project. A key finding of this article, namely the importance of an inclusive character of a today's policy on religion, will be a critical factor for the future policy on religion of the Canton Bern.

\section{For indexing purposes}

For decades the population of the Swiss Canton Bern consisted of citizens who belonged to one of the staterecognised churches, predominantly to the Bernese Reformed Church. The traditional confession-based Bernese state policy on religion therefore fulfilled its purpose. Today the loss of members among the state-recognised churches is obvious, together with the growing religious diversity and the growing population with no specific religious affiliation. 
This challenges the state policy on religion, which dates from a different period with a different socio-religious reality. This state of affairs raises many questions regarding the responsibility of a modern state in respect of religious issues, fair treatment of groups and citizens, and the state's neutrality and commitment to promoting religious peace. The key questions that challenge the traditional Bernese policy on religion are presented in this article. These questions indicate the need for revision of this state policy on religion.

\section{Acknowledgements}

Prof. Dr J.M. Vorster \& Prof. Dr A.L. Rheeder contributed as the promoters of the $\mathrm{PhD}$, from which this article is derived. They commented the R.P., and Prof. Dr J.M. Vorster commented on this submitted article.

\section{Competing interests}

The authors have declared that no competing interests exist.

\section{Authors' contributions}

M.G.I. is the main author of this article. J.M.V. \& A.L.R. contributed as the promoters of the $\mathrm{PhD}$, from which this article is derived. Both commented the R.P., and J.M.V. commented on this submitted article.

\section{Ethical considerations}

The ethics code of the TRREE (Training and Resources in Research Ethics Evaluation) programme on the ethics and the regulation of health research involving human participants were taken into consideration.

\section{Funding information}

This research received no specific grant from any funding agency in the public, commercial, or non-for-profit sectors.

\section{Data availability}

Data sharing is not applicable to this article as no new data were created or analysed in this study.

\section{Disclaimer}

The views and opinions expressed in this article are those of the authors and do not necessarily reflect the official policy of any affiliated agency of the authors.

\section{References}

Bortz, J. \& Döring, N., 2006, Forschungsmethoden und evaluation für human- und Sozialwissenschaftler, Springer, Berlin.

Canton Bern, 2015, Presentation of the State Council, Mr. Christoph Neuhaus, in the Commission of State Policy and Foreign Relations, in respect to the Report on the Relationship of State and Church in the Canton Bern (18 May 2015), viewed 26 January 2018, from https://www.jgk.be.ch/jgk/de/index/direktion/direktor/diereferate/Referate $\% 202015$.assetref/dam/documents/JGK/GS/de/Bericht $\% 20$ $\%$ C3\%BCber\%20das $\% 20$ Verh $\%$ C3\%A4ltnis $\% 20$ von $\% 20$ Kirche $\% 20$ und $\% 20$ Staat $\% 20$ im $\% 20$ Kanton $\% 20$ Bern.pdf.

Canton Bern, 2020a, Law on the Jewish Communities of 28 January 1997 (Status as of 1 Oct 2018), viewed 22 July 2020, from https://www.belex.sites.be.ch/frontend/ versions $/ 1514$ ?locale $=$ de
Canton Bern, 2020b, The relationship between church and state in the Canton of Bern, political conclusions and guidelines for the further development (18 March 2015), viewed 21 July 2020, from https://www.jgk.be.ch/jgk/de/index/ direktion/organisation/kirchen/Neues Landeskirchengesetz.assetref/dam/ direktion/organisation/kirchen/Neues_Landeskirchengesetz.assetref/dam/
documents/portal/Medienmitteilungen/de/2015/03/2015-03-27-kirche-staatbericht-rr-de.pdf.

Canton Bern, 2020c, Presentation of the report of the government on the relationship between church and state in the Canton of Bern, 2015 (Guiding Principles), viewed 25 July 2020, from https://www.be.ch/portal/de/index/mediencenter/ medienmitteilungen.assetref/dam/documents/portal/Medienmitteilungen/ medienmitteilungen.assetref/dam/documents/portal/Medienmitte
de/2015/03/2015-03-27-kirche-staat-referat-rr-neuhaus-mayer-de.pdf.

Canton Bern, 2020d, Department for interior and justice, 'Dossier', viewed 03 September 2020, from https://www.jgk.be.ch/jgk/de/index/direktion/ueber-diedirektion/dossiers.html.

Canton Bern, 2020e, Finance Department, Permanent resident population (15 years and older) by religion and denomination, in 2018, viewed 02 September 2020, from https://www.fin.be.ch/fin/de/index/finanzen/finanzen/statistik/bevoelk/ religionen.html.

Canton Bern, 2020f, Constitution of 6 June 1993 (Status as of 11 March 2015), viewed 06 October 2020, from https://www.admin.ch/opc/de/classified-compilation/ 19930146/index.html.

Canton Bern, 2020g, Bernese Decree on Hospital Care of 13 June 2013 (Status as of 1 February 2019), viewed 04 August 2021, from https://www.belex.sites.be.ch/ frontend/versions/1606/embedded_version_content .

Canton Bern, 2020h, Bernese Church Law of 21 March 2018 (Status as of 1 January 2020), viewed 06 October 2020, from www.belex.sites.be.ch/frontend/ versions/1512.

Canton Bern, 2020i, Request by the government of the Canton Bern regarding the Church Law (29 March 2017), viewed 01 January 2021, from https:// www.rr.be.ch/etc/designs/gr/media.cdwsbinary.RRDOKUMENTE.acq/ d099a26b38734168984f4eb48fd23c5c-332/5/PDF/2016.RRGR.835Vortrag--147029.pdf.

Cobb, M., 2015, 'Introduction to chaplaincy studies', in M. Cobb, C. Swift \& A. Todd (eds.), A handbook of chaplaincy studies. Understanding spiritual care in public places, pp. 1-12, Farnham, Ashgate.

Dehbi, A., 2020, 'Ausgrenzung kann junge Muslime radikalisieren', in SRF Schweizer Radio und Fernsehen, Sternstunde Religion (15 November 2020) viewed 22 November 2020, from https://www.srf.ch/kultur/gesellschaftreligion/antimuslimischer-rassismus-ausgrenzung-kann-junge-muslimeradikalisieren.

Dellsperger, R., 1991, 'Staat, Kirche und Politik im Kanton Bern von der Reformation bis in die Mitte des 20. Jahrhunderts', in R. Dellsperger, J.G. Fuchs, P. Gilg, F. Hafner \& W. Stähelin (eds.), Kirche - Gewissen des Staates?, pp. 117-181, Verlag Stämpfl + Cie AG, Bern.

Ecoplan, Ad!vocate, 2014, Das Verhältnis von Kirche und Staat im Kanton Bern. Eine Auslegeordnung, Ecoplan, Bern.

Engi, L., 2017, Die religiöse und ethische Neutralität des Staates, Schulthess, Zürich.

Göransson, Å., 2014, Contribution to the contributors of Society, The Commission for Government Support for Faith Communities, Bromma.

Guggisberg, K., 1958, Bernische Kirchengeschichte, Paul Haupt Verlag, Bern.

Heckel, M., 2009, 'Zur Zukunftsfähigkeit des deutschen "Staatskirchenrechts" oder "Religionsverfassungsrechts?"', in U. Di Fabio, M. Eifert \& P. M. Huber (eds.), Archiv des öffentlichen Rechts (no. 134), pp. 309-390, Mohr Siebeck, Tübingen.

Inniger, M., 2016, A theological-ethical evaluation of the Christian-Muslim dialogue in the Swiss army chaplaincy, PhD thesis, North-West University, Potchefstroom viewed 03 March 2019, from https://repository.nwu.ac.za/bitstream/ handle/10394/19661/Inniger_M_2016.pdf?sequence=1\&isAllowed=y.

Inniger, M., 2017, Religionspolitische Herausforderungen und Handlungsoptionen des Kantons Bern. Eine Auslegeordnung erstellt im Auftrag der Justiz-, Gemeinde- und Kirchendirektion des Kantons Bern (Entwurf). 1 May 2017, (unpublished), JustizGemeinde- und Kirchendirektion des Kantons Bern, Bern.

Inniger, M., 2018, Religionspolitische Auslegeordnung für den Kanton Bern: Kurzberich im Auftrag der Justiz-, Gemeinde- und Kirchendirektion des Kantons Bern (3 April 2018), viewed 02 September 2020, from https://www.jgk.be.ch/jgk/de/index/ direktion/ueber-die-direktion/dossiers.assetref/dam/documents/.

Inniger, M., 2019, 'Die Schweizer Armeeseelsorge und die Förderung des Religionsfriedens', in A. Berlis, M. Ploeger, K. Rohmann, P.-B. Smit, F. Vobbe \& W. Wysoczanski (eds.), Internationale Kirchliche Zeitschrift (Heft 2, 2019) pp. 81-98, viewed 10 November 2020, from https://www.ikz.unibe.ch/pdf/ Inniger_Armeeseelsorge_in_Internationale_Kirchliche_Zeitschrift_2019.pdf.

Inniger, M., Vorster, J.M. \& Rheeder, R., 2020, 'Changing religious landscapes challenge confession-based state policies on religion', In die Skriflig 54(1), a2527. https:// doi.org/10.4102/ids.v54i1.2527

Jecker, H., 2012, 'Täufer (Anabaptisten)', in Historisches Lexikon der Schweiz (14 August 2012), viewed 21 July 2020, from https://hls-dhs-dss.ch/de/ articles/011421/2012-08-14/.

Livenet.ch, 2007, Kanton Bern: Keine öffentlich-rechtliche Anerkennung für Freikirchen, viewed 22 July 2020, from https://www.livenet.ch/themen/kirche und co/ kirchen_gemeinden_werke/133517-keine_oeffentlichrechtliche_anerkennung_ fuer_freikirchen.html.

Pfaff-Czarnecka, J., 2009, 'Accommodating religious diversity in Switzerland', in P. Bramadat \& M. Koenig (eds.), International migration and the governance of religious diversity (Queen's policy studies), pp. 225-257, McGill-Queen's University Press, Montreal. 
Portier, P., 2017, 'Les regimes de laïcité en Europe', in A. Dieckhoff \& P. Portier (eds.) Religion et politique, pp. 211-222, Presses de SciencesPo, Paris.

Reformed Churches Bern-Jura-Solothurn, 1990, Statistik 1990, viewed 10 April 2020 from https://www.refbejuso.ch/fileadmin/user_upload/Downloads/Zentrale Dienste/kirchl. Statistik/ZD INF_d_Statistik1990.pdf.

Sarbach, N., 2017, 'Neuhaus bittet Täufer um Verzeihung: Regierungsrat Christoph Neuhaus (SVP) bittet die Täufer um Verzeihung für die Repressionen, unter denen die Gemeinschaft über Jahrhunderte zu leiden hatte', in Berner Zeitung (17 Nover 2017), viewed 21 July 2020, from https://ww bernerzeitung. (17 November 2017), viewed 21 July 2020, from https://www.bernerzeitung. $\mathrm{ch} / \mathrm{region} / \mathrm{kanton}-\mathrm{bern} / \mathrm{neuhaus-bittet-taeufer-um-verzeihung/}$
story/30038204.

Schmid, P., 2017, 'Kirchengesetz im Berner Grossen Rat, Postulat "Kleine Anerkennung mit grosser Auswirkung auf den gesellschaftlichen Zusammenhalt"', in Landeskirchenforum (9 July 2017), viewed 31 January 2020, from https:// landeskirchenforum.ch/sites/default/files/postulat_kleine_anerkennung_mit landeskirchenforum.ch/site
grosser_auswirkung.pdf.

Schuppert, G.F., 2017, Governance of diversity. Zum Umgang mit kultureller und religiöser Pluralität in säkularen Gesellschaften, Campus Verlag, Frankfurt.

Swiss Confederation, 2020a, Federal Constitution of 18 April 1999 (Status as of 1 January 2020), viewed 04 October 2020, from https://www.admin.ch/opc/en/ classified-compilation/19995395/index.html.
Swiss Confederation, 2020b, Civil Code of 10 December 1907 (Status as of 1 July 2020), viewed 03 January 2021, from https://www.admin.ch/opc/en/classifiedcompilation/19070042/index.html.

Swiss Federal Statistic Office, 2020a, Development of the religious landscape, viewed 02 September 2020, from https://www.bfs.admin.ch/bfs/en/home/statistics/ population/languages-religions/religions.assetdetail.11527931.html.

Swiss Federal Statistic Office, 2020b, Religious affiliation since 2015, viewed 11 April 2020, from https://www.bfs.admin.ch/bfs/de/home/statistiken/bevoelkerung/ sprachen-religionen/religionen.assetdetail.11607242.html.

Swiss Federal Supreme Court, 1992, Federal Court Decisions (Bundesgerichtsentscheide BGE 118 la 58), viewed 03 March 2019, from http://relevancy.bger.ch/php/clir/ http/index.php?lang=de\&zoom=\&type=show_document\&highlight docid $=$ atf $\% 3 \mathrm{~A} \% 2 \mathrm{~F} \% 2 \mathrm{~F} 118-\| 1-58 \% 3$ Ade.

Training and Resources in Research Ethics Evaluation (TRREE), 2017, TRREE on-line training programme on the ethics and regulation of health research involving human participants, viewed 03 July 2017, from http://elearning.trree.org/.

Van Bijsterveld, S., 2018, State and religion. Re-assessing a mutual relationship, Eleven International Publishing, The Hague.

Weller, P., 2005, Time for a change. Reconfiguring religion, state and society, T\&T Clark International, London. 